\title{
The re-discovered Maculinea rebeli (Hirschke, 1904): Host ant usage, parasitoid and initial food plant around the type locality with taxonomical aspects (Lepidoptera, Lycaenidae)
}

\author{
András Tartally', Anton Koschuh', Zoltán Varga' \\ I Department of Evolutionary Zoology and Human Biology, University of Debrecen, Egyetem tér 1, H-4032 \\ Debrecen, Hungary 2 Steyrergasse 72/8 A-8010 Graz, Austria
}

Corresponding author: András Tartally (tartally.andras@science.unideb.hu)

Academic editor: C. Peña | Received 24 January 2014 | Accepted 14 April 2014 | Published 29 April 2014

Citation: Tartally A, Koschuh A, Varga Z (2014) The re-discovered Maculinea rebeli (Hirschke, 1904): Host ant usage, parasitoid and initial food plant around the type locality with taxonomical aspects (Lepidoptera, Lycaenidae). ZooKeys 406: 25-40. doi: 10.3897/zookeys.406.7124

\begin{abstract}
The taxonomy of the myrmecophilous Maculinea alcon group (Lepidoptera: Lycaenidae) is highly debated. The host-plant and host-ant usage of these butterflies have conventionally been important in their identification. Maculinea 'rebeli' has generally been considered to be the xerophilous form of $M a$. alcon (Ma. alcon $X$ hereafter) with Gentiana cruciata as initial food plant. However, the type locality and all other known sites of $\mathrm{Ma}$. rebeli are found above the coniferous zone, and are well separated from the lower regions where $\mathrm{Ma}$. alcon $\mathrm{X}$ sites are found. Furthermore, no food plant and host ant data for the nominotypic $M a$. rebeli have yet been published. Our aim was therefore to identify the host ant(s) of Ma. rebeli around the type locality and compare this with the host ant usage of nearby Ma. alcon X. Nests of Myrmica spp. (Hymenoptera: Formicidae) close to the host plants were opened on one Ma. alcon X (host plant: Gentiana cruciata) and two Ma. rebeli (host plant: Gentianella rhaetica, first record, confirmed by oviposition and emerging larvae) sites just before the flying period, to find prepupal larvae and pupae. Three $M y r-$ mica species (My. lobulicornis, My. ruginodis, My. sulcinodis) were found on the two Ma. rebeli sites, which parasitized exclusively My. sulcinodis (22 individuals in 7 nests). On the Ma. alcon X site Myrmica sabuleti and $M y$. lonae were found, with My. sabuleti the exclusive host (51 individuals in 10 nests). Ichneumon cf. eumerus parasitized both butterflies. The results highlight the differentiation of Maculinea rebeli from $\mathrm{Ma}$. alcon $X$, from both conservation biological and ecological points of view. Thus, it should be concluded that $M a$. rebeli does not simply represent an individual form of $M a$. alcon but it can be considered as at
\end{abstract}

$\dagger \quad 1970-2013$

Copyright András Tartally et al.. This is an open access article distributed under the terms of the Creative Commons Attribution License (CC BY 4.0), which permits unrestricted use, distribution, and reproduction in any medium, provided the original author and source are credited. 
least an ecological form adapted to high mountain conditions both in its initial food plant and host ant species. In addition, it should be emphasized that $M a$. alcon $X(=M a$. rebeli auct. nec Hirschke) cannot be synonymised with Ma. rebeli (Hirschke, 1904).

\section{Keywords}

Styrian Alps, nominotypic Maculinea rebeli, Myrmica sulcinodis, My. sabuleti, Gentianella rhaetica, Ichneumon cf. eumerus

\section{Introduction}

Although Maculinea van Eecke, 1915 (Lepidoptera, Lycaenidae) has been synonymised with Phengaris Doherty, 1890 (see: Fric et al. 2007, Pech et al. 2007, Kudrna and Fric 2013) we continue to use the well-established generic name here, since (i) the case is still undecided by the International Commission on Zoological Nomenclature (ICZN 2012) and strong arguments for the precedence of Maculinea over Phengaris have been made (Balletto et al. 2010, and Comments on this Case); and (ii) Ugelvig et al. (2011) have shown that Maculinea represents a monophyletic sub-clade and we agree with their conclusion: "We recommend that the nomenclatural debate is delayed until irrefutable evidence is provided".

Maculinea (abbreviated as "Ma." below) butterflies are endangered species (Munguira and Martín 1999, Maes et al. 2004, Settele et al. 2005) and their larvae are social parasites of Myrmica Latreille, 1804 (Hymenoptera: Formicidae; abbreviated as "My." below) ant colonies (Thomas et al. 1989). Larvae of Maculinea alcon ([Denis \& Schiffermüller], 1775) initially feed on the seeds of gentian plants for about a month and are later taken in and raised by Myrmica colonies (Thomas et al. 1989). They have a "cuckoo" strategy, in which they mimic the odour (Thomas and Settele 2004, Nash et al. 2008, Akino et al. 1999) and sound (Barbero et al. 2009) of the host ant species, and are therefore fed like an ant larva (Thomas and Elmes 1998), although they also sometimes prey directly on the ant brood (Tartally 2004). The caterpillars develop within the host ant nest during the autumn, winter and spring, and will then either pupate there, or continue development for an additional year (Schönrogge et al. 2000, Witek et al. 2006).

There are regional and local differences between the host ant usage of different populations (e.g. Elmes et al. 1994, Als et al. 2002, Höttinger et al. 2003, Steiner et al. 2003, Sielezniew and Stankiewicz 2004, Stankiewicz et al. 2005, Tartally et al. 2008, Witek et al. 2008, Tartally et al. 2013). Knowledge of the local host ant species is vital to understand the biogeography, conservation and evolutionary biology of Maculinea spp. (Settele et al. 2005, Settele and Kühn 2009), and may also have some taxonomic implications. Furthermore, the host ant and host plant usage of $M a$. alcon has been thought to be important for taxonomic separation (Thomas et al. 1989) of the hygrophilous (" $M a$. alcon $H$ ' below) and the xerophilous (' $M a$. alcon $X$ ) form of $M a$. alcon, although recent studies have been unable to show any consistent genetic separation between these two butterflies (Als et al. 2004, Bereczki et al. 2005, Ugelvig et al. 2011). 
Despite this, Ma. alcon $X$ is still generally (and erroneously, see Kudrna and Fric 2013) referred to as 'Ma. rebeli (Hirschke, 1904)' (e.g. Elmes et al. 1998, Steiner et al. 2003, Stankiewicz et al. 2005, Tartally et al. 2008). Some Balkan, Caucasian and Central Asian mountainous populations of $\mathrm{Ma}$. alcon have also been referred to as $\mathrm{Ma}$. 'rebeli' (Kolev 2002, Savela 2014, Tuzov 2000).

However, a recent paper (Habeler 2008) called our attention to the fact that $M a$. alcon $X(=$ Ma. rebeli auctorum nec Hirschke, 1904$)$ is not likely synonymous with $M a$. rebeli described by Hirschke (1905) from the type locality, based on external morphological features and the different habitat types in which they occur. It has now been demonstrated that $M a$. rebeli auct. does not represent a distinct species, but rather the xerophilous form of $M a$. alcon (Ma. alcon X). It feeds initially typically on $G$. cruciata (Bereczki et al. 2005, Pecsenye et al. 2007, Sielezniew et al. 2012) then using mainly Myrmica schencki Viereck, 1903, My. sabuleti Meinert, 1861 and some other available Myrmica species (e.g. Elmes et al. 1998, Meyer-Hozak 2000, Steiner et al. 2003, Stankiewicz et al. 2005, Tartally et al. 2008). However, following the paper of Habeler (2008), we realised that no reliable host ant and initial food plant data have been published for the nominotypic Ma. rebeli (called simply Ma. rebeli hereafter).

The main reason for our study is that the type locality and the other suggested sites of $M a$. rebeli are above the coniferous zone and well-separated by spruce forests (see Figure 7 in Habeler 2008) from the lower regions where $M a$. alcon $X$ occurs in grasslands (mostly extensive pastures) with G. cruciata. Furthermore, from our personal observations (see Materials and Methods), Ma. rebeli uses Gentianella rhaetica (A. Kern. \& Jos. Kern.) Á. Löve \& D. Löve rather than G. cruciata at higher altitudes, as the latter plant is not available in that zone (see the questions about host plant usage of Kudrna and Fric 2013). Similarly, we reasoned that the available Myrmica species are likely to be different for $M a$. rebeli and $M a$. alcon $X$ within the same region because of changes in available niches with increasing altitude (Elmes et al. 1998, Glaser 2006). It is therefore important to know the host ant use and specificity of Ma. rebeli and $M a$. alcon $X$ around the type locality of $M a$. rebeli to help in answering the question of whether these two butterflies should be treated as the same or different forms or species.

\section{Methods}

Three sites within the Hochschwab area (Styrian Alps, Austria; Figs 1-4) were visited between the $22^{\text {nd }}$ and $24^{\text {th }}$ June 2012 (just before the flying period). Two $M a$. rebeli habitats above the coniferous zone were investigated, one at Zeiritz $(47.486 \mathrm{~N}$, 14.723E, ca $1750 \mathrm{~m}$ a.s.l.) and another at Präbichl (47.512N, $14.938 \mathrm{E}$, ca $1600 \mathrm{~m}$ a.s.l.). Both sites are sparsely covered by calcareous alpine Sesleria varia (Jacq.) Wettst.Carex sempervirens Vill. grassland (Seslerio-Semperviretum) vegetation on stony and sunny slopes, with bare limestone rocks (Figs 1-3, compare with Figs 8-10 in Habeler 2008). We regularly found eggs on Gentianella rhaetica (Fig. 5; det. K. Zernig, 


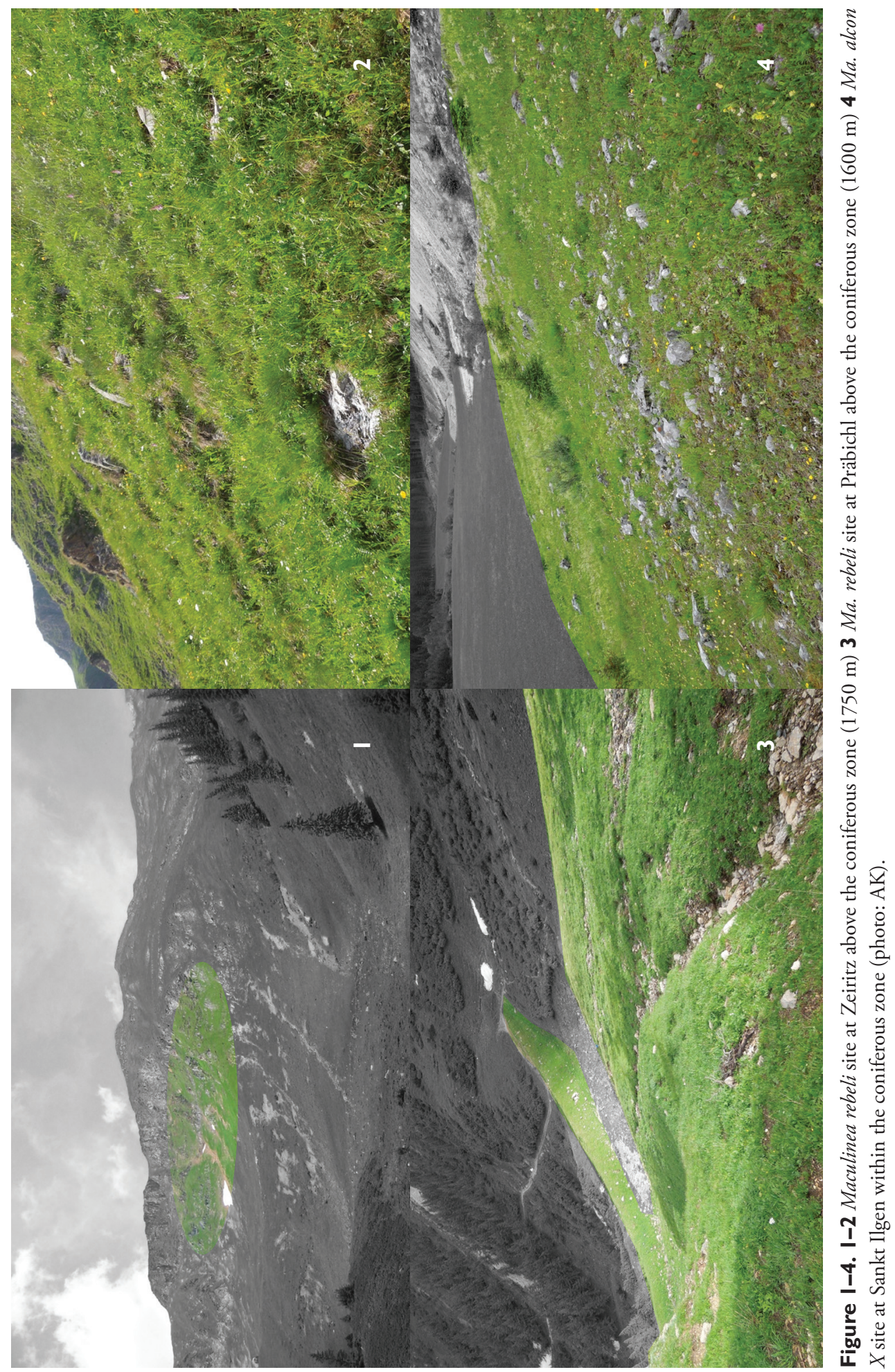


Universalmuseum Joanneum; it belongs to the Gentianella germanica agg.: Greimler et al. 2011) on both sites, and caterpillars readily developed on and emerged from this plant (AK and AT, pers. observ.). The third site is a calcareous grazed meadow (Fig. 4) within the coniferous zone (Sankt Ilgen: 47.562N, 15.153E, ca $810 \mathrm{~m}$ a.s.l.) where $M a$. alcon $X$ uses Gentiana cruciata as initial host plant (an adjacent similar site for $M a$. alcon $X$ has already been described by Bereczki et al. 2005 and Pecsenye et al. 2007).

The host ant specificity of the Ma. alcon X population at Sankt Ilgen was checked by searching for Myrmica spp. nests within $2 \mathrm{~m}$ of G. cruciata plants (see details: Tartally et al. 2008). However, this method was not possible in the case of the two Ma. rebeli sites (at Präbichl and Zeiritz) as Gentianella rhaetica plants are rather small before the flying period of Ma. rebeli, and were only rarely visible. We instead worked within patches where G. rhaetica plants were found in the previous year (although it should be noted that we were often not sure of the actual presence of plants in 2012, as G. rhaetica is biannual). When a Myrmica nest was found, it was opened as carefully as possible to search for Maculinea larvae and pupae. Five to ten workers were collected from each ant nest and preserved in 75\% ethanol for identification in the laboratory (following keys in Seifert 1988, Radchenko and Elmes 2010, Czechowski et al. 2012).

Host ant specificity was calculated based on the number of fully grown butterfly larvae, pupae and exuvia found (i.e., not including small larvae: see results) in two ways (see details: Tartally et al. 2008): p1 is the 2-tailed probability from a Fisher exact test of heterogeneity in infection of host ant nests (as implemented at http://www.quantitativeskills.com/sisa/), and $\mathrm{p} 2$ is the probability from a randomization test of ant nests between species (using the program MacSamp; Nash 2014). We should emphasize that our data on the host ant specificity of Ma. rebeli and Ma. alcon X should be compared cautiously, as our certainty of the presence of host plants differed for Ma. rebeli and Ma. alcon X (see above). Furthermore, excavating complete nests of Myrmica spp. was relatively easy in the deep humus of the Ma. alcon X site, but was much more difficult in the rocky Ma. rebeli sites.

\section{Results}

Altogether 53 Myrmica nests were found on the three sites (Table 1), consisting of 52 nests of five Myrmica species and one empty (presumably recently vacated) but Maculinea-infested nest which was similar in appearance to nearby My. sabuleti nests. Only nests of My. sabuleti and of the closely related (Radchenko and Elmes 2010) My. lonae Finzi, 1926 were found at the Ma. alcon X site (Sankt Ilgen), whereas the Myrmica composition of the two $M a$. rebeli sites was totally different from this: My. ruginodis Nylander, 1846 and My. sulcinodis Nylander, 1846 were found at both sites, plus $M y$. lobulicornis Nylander, 1857 at Präbichl.

Nine nests of $M y$. sulcinodis were infested with $33 \mathrm{Ma}$. rebeli larvae, pupae and exuvia at Präbichl and Zeiritz in total, of which 11 caterpillars were so small as to 

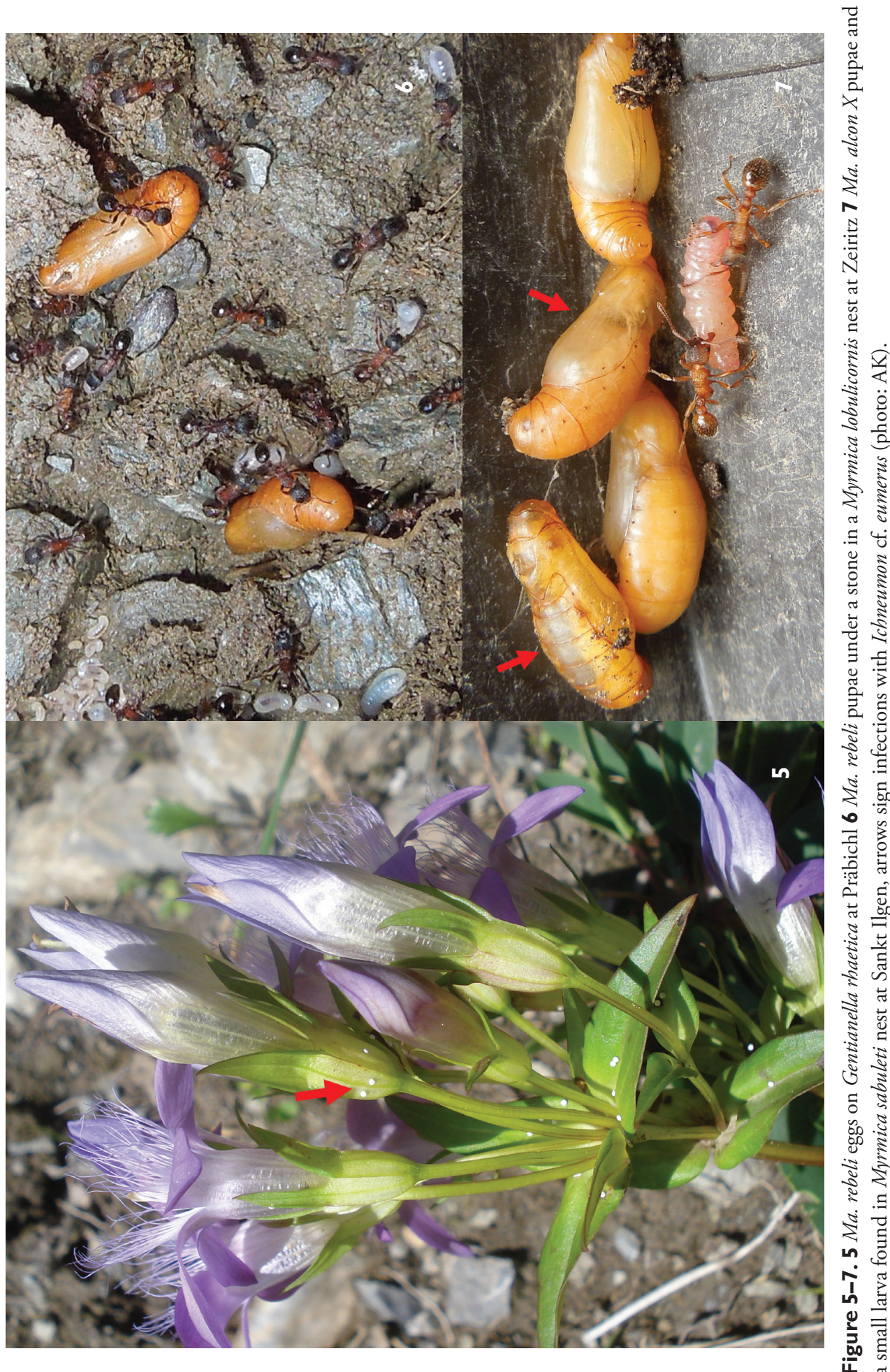
The re-discovered Maculinea rebeli (Hirschke, 1904): Host ant usage, parasitoid...

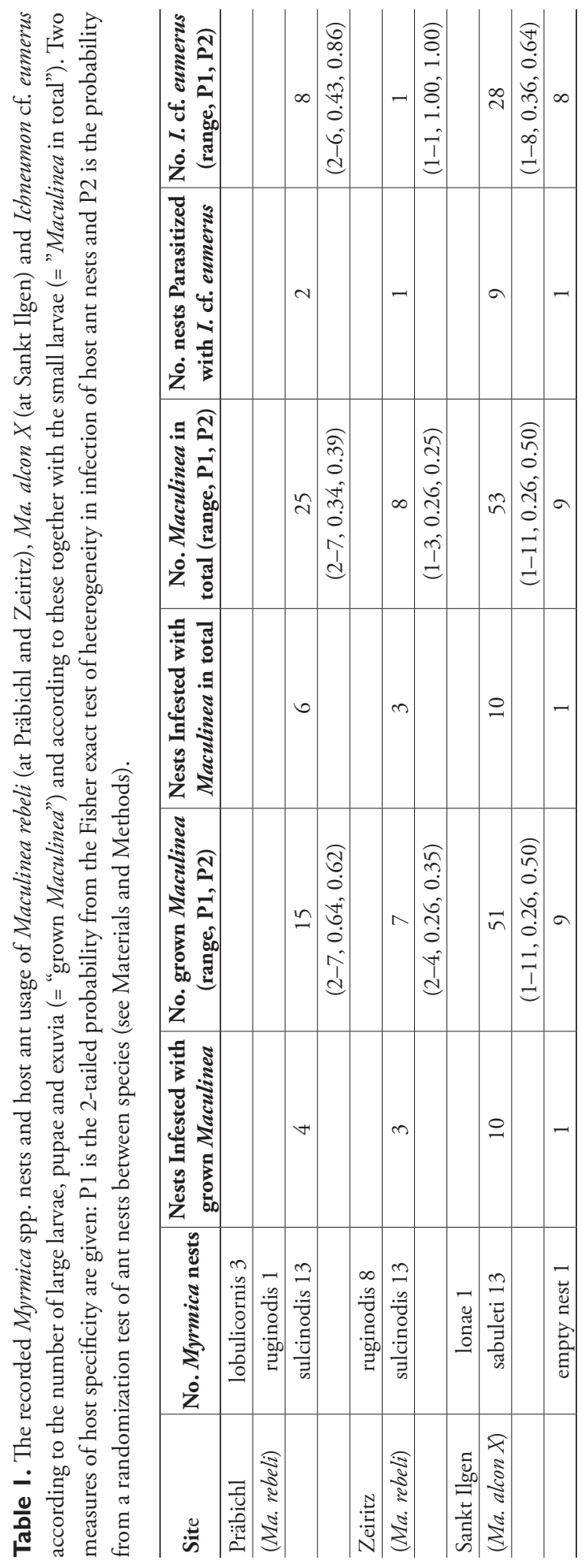


be two-year developing larva after their first winter. There were 15 pupae in total on these two sites, nine of which (60\%) proved to be infected with Ichneumon cf. eumerus Wesmael, 1857.

Ten nests of My. sabuleti were infested at Sankt Ilgen with $53 \mathrm{Ma}$. alcon X larvae, pupae and exuvia, but only two caterpillars were so small as to be two-year developing larvae. There were nine "orphaned" Ma. alcon X pupae in the empty nest, which were dirty and showed visible signs of external mould. There were 36 pupae in total, 28 of which $(77.8 \%)$ were infected with Ichneumon cf. eumerus.

\section{Discussion}

Based on the character of the habitat, the figures published by Habeler (2008) and photographs of $M a$. rebeli imagos taken by AK (Figs 8-9), we are confident that we have re-discovered two populations that correspond to the description of Hirschke (1905). Our data confirm that Ma. rebeli is (at least) an ecological form found at high altitudes, and with host ant and initial food plant distinct from the adjacent populations of Ma. alcon $X$ (Ma. rebeli auct. nec Hirschke). It is unlikely to be a mere individual form characterised "by the presence of a band of whitish or silver-greyish spots in the blue ground colour in the submarginal band adjacent to the marginal black line on the upper side of wings, particularly well pronounced on the hind wings and especially in the +" (see Kudrna and Fric 2013 page 117, which is a misinterpretation of the original German text of Hirschke (1905): 109-110: „Am Innenwinkel der Vorderflügel zeigt sich in Zelle 2 und 3 eine auffallende Aufhellung, welche sich auf die Hinterflügel fortsetzt und gegen den Innenwinkel derselben sogar die Form einer Antemarginalbinde gewinnt."). Furthermore, the specimens figured by Habeler (2008) also clearly show this character of $M a$. rebeli but they are simply darker than the type series of Hirschke (1905) due to the circumstance that they were captured quite recently (1978-2005) while the type series was collected in 1904.

To avoid further confusion, we argue that the true Ma. rebeli occurs in the Hochschwab area above the coniferous zone (between c.a. 1500 and $2000 \mathrm{~m}$ ) on slightly covered stony and sunny slopes with uncovered chalk rocks, where G. rhaetica is the only recorded initial host plant, and $M y$. sulcinodis is the only recorded host ant species so far. We still need to confirm the observation of Habeler (2008) that these high altitude habitats are usually small, fragmented, and often located on steep and inaccessible (see Fig. 1) slopes, but it does seem that these populations have remained unknown to (or neglected by) most authors (see Kudrna and Fric 2013).

As far as we know, our observations are the first data on the host ant specificity of $M a$. rebeli around the type locality, and hence, we maintain, of the host ant specificity of $M a$. rebeli. Earlier data about the host ant specificity of $M a$. 'rebeli' (e.g. Elmes et al. 1998, Meyer-Hozak 2000, Steiner et al. 2003, Stankiewicz et al. 2005, Tartally et al. 2008) should instead be considered as data about the host ant specificity of $M a$. alcon X (see Introduction and Habeler 2008). While Ma. rebeli was found exclusively 


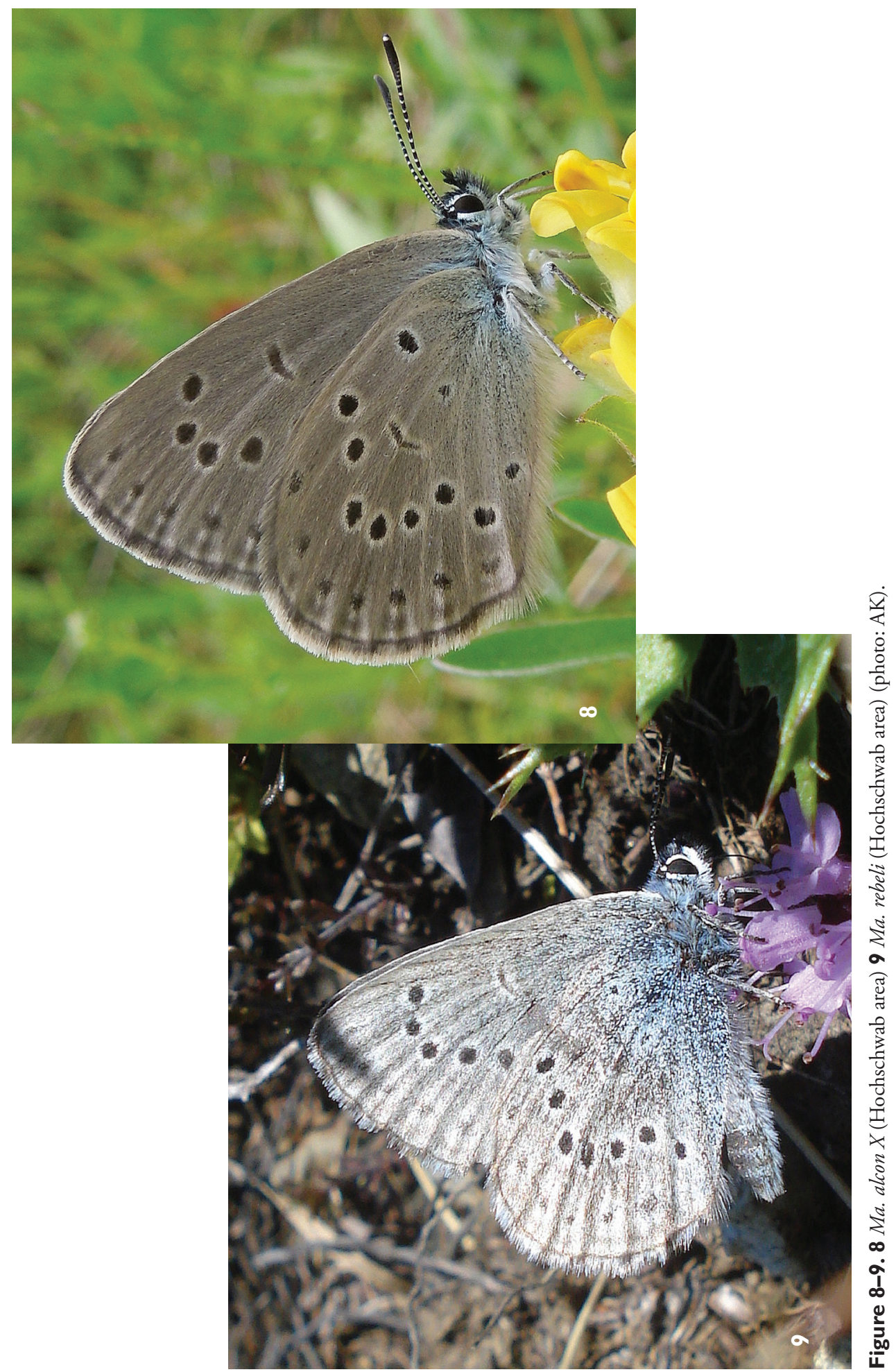


in My. sulcinodis nests at Zeiritz and Präbichl, the works just cited mention Ma. alcon X generally from nests of Myrmica schencki or My. sabuleti and from some other locally available Myrmica species (My. lonae; My. scabrinodis Nylander, 1846; My. specioides Bondroit, 1918; My. rugulosa Nylander, 1849; and My. ruginodis). However, we cannot rule out the discovery of other host ants of Ma. rebeli in the Hochschwab region, following more intensive work. H.C. Wagner (see Kudrna and Fric 2013) also found Myrmica sulcinodis, My. ruginodis and My. lobulicornis as available Myrmica species on $M a$. rebeli sites, plus one nest of My. scabrinodis, and also suggested My. lobicornis Nylander, 1846 as a potentially available but unrecorded species. Jutzeler (1989) has previously recorded $M y$. sulcinodis interacting with a full-grown larva of $M a$. 'rebeli' in the Swiss alps, although it was unclear whether this was a host nest or opportunistic predation (see also: Kudrna and Fric 2013). Although he did not record the altitude of this observation, it is notable that he also observed oviposition by Ma. 'rebeli' on Gentianella germanica (Willd.) E.F.Warb. on the same site (Jutzeler 1988). This region is distant and isolated by high mountains from the type locality of Ma. rebeli. Genetic studies and more knowledge about the host ant specificity of this Swiss population would be necessary to decide whether it is really Ma. rebeli (and e.g. not Ma. alcon X) and if its main host ant is really My. sulcinodis. Here it should be noted that specimens, phenotypically completely identical with the type specimens of Ma. rebeli, have also been collected from some high mountain habitats of Switzerland (Pontresina, 21. 07. 1907, leg. F.W. Dadd, coll. Zoological State Collection, Munich, checked by ZV).

Our results for $M a$. alcon $X$, showing $M y$. sabuleti as host, are in agreement with previous studies (e.g. Meyer-Hozak 2000, Tartally et al. 2008) that My. sabuleti is one of the most important host ants of this butterfly, and which has been already identified as the main host in other Austrian sites by Steiner et al. (2003).

The presence of $I$. cf. eumerus in Maculinea pupae appears to be a good indication that a given ant species is a suitable host ant of Maculinea butterflies (Thomas et al. 2002), so the relatively high infestation rate by the parasitoid is consistent with $M y$. sabuleti being a suitable host of $M a$. alcon $X$, and with $M y$. sulcinodis being a suitable host of Ma. rebeli in the sites studied here.

The one empty Myrmica nest found to be infested with Ma. alcon X confirms that colonies of various Myrmica species can migrate (Radchenko and Elmes 2010). Therefore it could potentially happen that a host Myrmica colony moves out and leaves the Maculinea pupae in the nest and another Myrmica species occupies the empty nest, complete with Maculinea pupae, leading to an erroneously recorded 'secondary host ant' ('Thomas et al. 2005).

It is almost certain that Manica rubida Latreille, 1802 is not available as a potential host for the populations studied here, despite the presence of this ant in this region. Manica rubida is closely related genetically (Jansen and Savolainen 2010), and similar chemically (Errard et al. 2006), to Myrmica spp. and shows potential suitability as a host of the Ma. alcon group in the laboratory (Tartally 2004). This ant is common in the nearby sites of both butterflies, typically in the border of spruce forests, but was not found in 
the patches with Gentiana cruciata or Gentianella rhaetica. It also should be noted that despite the common presence of other gentian species (e.g. Gentiana asclepiadea L., see also: Kudrna and Fric 2013) in this region, Maculinea eggs were never observed on them.

The unusual host ant use of Ma. rebeli in the Alpine sites could be constrained by the distinctive composition of the Myrmica community found there. Although Maculinea populations can adapt to locally available Myrmica species (e.g. Nash et al. 2008, Tartally 2005, Tartally et al. 2013), the unique combination of host ant and host plant usage of these Ma. rebeli populations means that the nominotypic Ma. rebeli should be treated as a distinct Conservationally Significant Unit (see Maes et al. 2004), separated biologically and ecologically from both $\mathrm{Ma}$. alcon $\mathrm{X}$ and $\mathrm{Ma}$. alcon $\mathrm{H}$. Further studies on the host ant and host plant specificity of $M a$. rebeli and genetic comparison of these butterflies is necessary to qualify the degree of ecological and genetic relationships within the Ma. alcon group, and also to draw well-supported taxonomical conclusions on the status of the nominotypical Maculinea rebeli versus Ma. rebeli auct. (Ma. alcon X).

\section{Conclusion}

It should be concluded that $M a$. rebeli does not simply represent an individual form of Ma. alcon (as considered by Kudrna and Fric 2013) but it should be considered as at least an ecological form adapted to high mountain conditions both in its initial food plant and host ant species. In addition, it should be emphasized that $M a$ alcon $X(=M a$. rebeli auct. nec Hirschke) cannot be synonymised with Ma. rebeli (Hirschke, 1904).

\section{Acknowledgements}

We dedicate this manuscript to the memory of our co-author and friend Anton Koschuh (Fig. 10) who unfortunately could not see the final version of this paper. This survey could not have been carried out without his initiation, enthusiasm and deep knowledge of the habitats. This publication is also dedicated to the memory of Prof. Klaus Horstmann, who provided invaluable assistance in confirming our determinations of Ichneumon eumerus in previous studies (e.g. Tartally 2008, Tartally et al. 2013) but sadly passed away before he could be involved in this current work.

We are grateful for the help on the manuscript for David R. Nash, Enikő Tóth, Gábor Sramkó and two anonymous referees.

AT was supported by a Marie Curie Career Integration Grant within the 7th European Community Framework Programme, by the TÁMOP-4.2.2/B-10/1-2010-0024 project (the project is co-financed by the European Union and the European Social Fund) and by a 'Bolyai János' scholarship of the Hungarian Academy of Sciences (MTA). AK was supported by the permission of the Nature Conservation Authority of Styria. ZV was supported by the Hungarian National Science Foundation (OTKA 84071). 


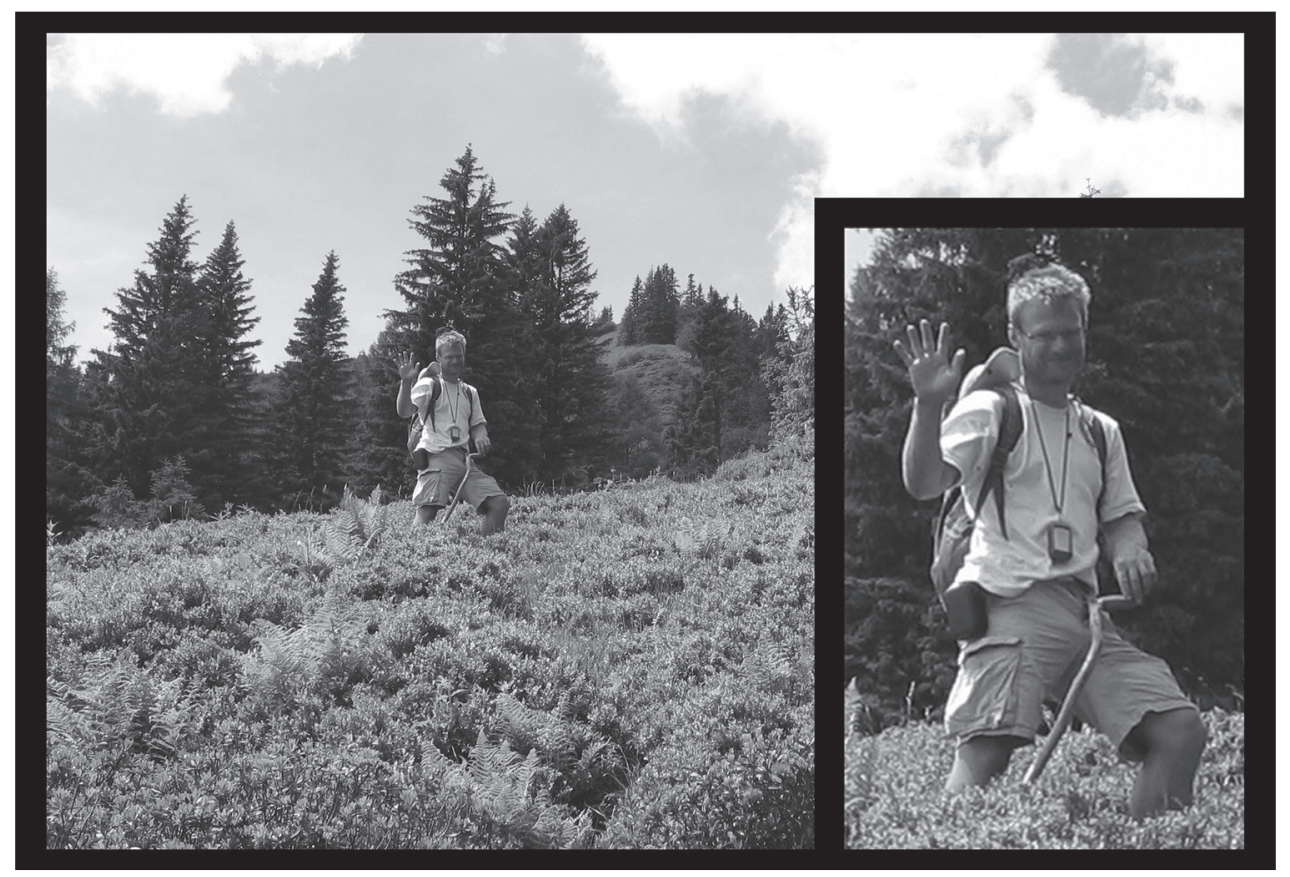

Figure I0. Anton Koschuh on his way to Zeiritz (23.06.2012) (photo: AT).

\section{References}

Akino T, Knapp JJ, Thomas JA, Elmes GW (1999) Chemical mimicry and host specificity in the butterfly Maculinea rebeli, a social parasite of Myrmica ant colonies. Proceedings of the Royal Society of London, Series B 266: 1419-1426. doi: 10.1098/rspb.1999.0796

Als TD, Nash DR, Boomsma JJ (2002) Geographical variation in host-ant specificity of the parasitic butterfly Maculinea alcon in Denmark. Ecological Entomology 27: 403-414. doi: 10.1046/j.1365-2311.2002.00427.x

Als TD, Vila R, Kandul NP, Nash DR, Yen S-H, Hsu Y-F, Mignault AA, Boomsma JJ, Pierce NE (2004) The evolution of alternative parasitic life histories in large blue butterflies. Nature 432: 386-390. doi: 10.1038/nature03020

Balletto E, Bonelli S, Settele J, Thomas JA, Verovnik R, Wahlberg N (2010) Case 3508 Maculinea Van Eecke, 1915 (Lepidoptera: Lycaenidae): proposed precedence over Phengaris Doherty, 1891. The Bulletin of zoological nomenclature 67: 129-132. http://iczn.org/content/case3508-maculinea-van-eecke-1915-lepidoptera-lycaenidae-proposed-precedence-over-phengaris

Barbero F, Thomas JA, Bonelli S, Balletto E, Schönrogge K (2009) Queen ants make distinctive sounds that are mimicked by a butterfly social parasite. Science 323: 782-5. doi: 10.1126/science. 1163583

Bereczki J, Pecsenye K, Peregovits L, Varga Z (2005) Pattern of genetic differentiation in the Maculinea alcon species group (Lepidoptera, Lycaenidae) in Central Europe. Journal of Zoological Systematics and Evolutionary Research 43: 157-165. doi: 10.1111/j.14390469.2005.00305.x 
Czechowski W, Radchenko A, Czechowska W, Vepsäläinen K (2012) The ants of Poland with reference to the myrmecofauna of Europe - Fauna Poloniae Vol. 4 New series. Museum and Institute of Zoology of the Polish Academy of Sciences and Natura optima dux Foundation, Warszawa, $496 \mathrm{pp}$.

Elmes GW, Thomas JA, Hammarstedt O, Munguira ML, Martin J, van der Made JG (1994) Differences in host-ant specificity between Spanish, Dutch and Swedish populations of the endangered butterfly, Maculinea alcon (Denis et Schff.) (Lepidoptera). Memorabilia Zoologica 48: 55-68.

Elmes GW, Thomas JA, Wardlaw JC, Hochberg ME, Clarke RT, Simcox DJ (1998) The ecology of Myrmica ants in relation to the conservation of Maculinea butterflies. Journal of Insect Conservation 2: 67-68. doi: 10.1023/A:1009696823965

Errard C, Hefetz A, Jaisson P (2006) Social discrimination tuning in ants: template formation and chemical similarity. Behavioral Ecology and Sociobiology 59: 353-363. doi: 10.1007/ s00265-005-0058-z

Fric Z, Wahlberg N, Pech P, Zrzavý J (2007) Phylogeny and classification of the Phengaris-Maculinea clade (Lepidoptera: Lycaenidae): total evidence and phylogenetic species concepts. Systematic Entomology 32: 558-567. doi: 10.1111/j.1365-3113.2007.00387.x

Glaser F (2006) Biogegography, diversity, and vertical distribution of ants (Hymenoptera: Formicidae) in Vorarlberg, Austria. Myrmecological News 8: 263-270. http://myrmecologicalnews. org/cms/images/pdf/volume8/mn8_263-270_non-printable.pdf

Greimler J, Park J-M, Schneeweiss H (2011) Gentianella (Gentianaceae): A model taxon for evolution in the Alps. Taxon 60: 427-435. http://www.ingentaconnect.com/content/iapt/ $\operatorname{tax} / 2011 / 00000060 / 00000002 / \operatorname{art} 00012$

Habeler H (2008) Die subalpin-alpinen Lebensräume des Bläulings Maculinea rebeli (Hirscke, 1904) in den Ostalpen (Lepidoptera, Lycaenidae). Joannea Zoologie 10: 143-164. http:// www.landesmuseum.at/pdf_frei_remote/JoanZoo_10_0143-0164.pdf

Hirschke H (1905) Eine neue hochalpine Form der Lycaena Alcon F. aus den steirischen Alpen. Jahres-Bericht des Wiener Entomol Vereines 15: 1-3.

Höttinger H, Schlick-Steiner BC, Steiner FM (2003) The Alcon blue Maculinea alcon (Lepidoptera: Lycaenidae) in eastern Austria: status and conservation measures. Ekologia (Bratislava) 22: 107-118.

ICZN (2012) Official Lists and Indexes of Names in Zoology, Updated March 2012. http:// iczn.org/sites/iczn.org/files/officialists.pdf [Accessed: 08 April 2014]

Jansen G, Savolainen R (2010) Molecular phylogeny of the ant tribe Myrmicini (Hymenoptera: Formicidae). Zoological Journal of the Linnean Society 160: 482-495. doi: 10.1111/j.10963642.2009.00604.x

Jutzeler D (1988) Fund von Maculinea rebeli (Hirschke, 1904) im Glarnerland (Lepidoptera, Lycaenidae). Mitteilungen der Entomologischen Gesellschaft Basel 38: 124-125.

Jutzeler D (1989) Maculinea rebeli (Hirschke) Ein Raupenfund im Glarnerland (Lepidoptera: Lycaenidae). Mitteilungen der Entomologischen Gesellschaft Basel 39: 92-93.

Kolev Z (2002) The species of Maculinea van Eecke, 1915 in Bulgaria: distribution, state of knowledge and conservation status (Lycaenidae). Nota Lepidopterologica 25: 177-190. 
Kudrna O, Fric ZF (2013) On the identity and taxonomic status of Lycaena alcon rebeli Hirschke, 1905 - a long story of confusion and ignorance resulting in the fabrication of a "ghost species" (Lepidoptera: Lycaenidae). Nachrichten des Entomologischen Vereins Apollo 34: 117-124.

Maes D, Vanreusel W, Talloen W, Dyck H Van (2004) Functional conservation units for the endangered Alcon Blue butterfly Maculinea alcon in Belgium (Lepidoptera: Lycaenidae). Biological Conservation 120: 229-241. doi: 10.1016/j.biocon.2004.02.018

Meyer-Hozak C (2000) Population Biology of Maculinea rebeli (Lepidoptera: Lycaenidae) on the Chalk Grasslands of Eastern Westphalia (Germany) and Implications for Conservation. Journal of Insect Conservation 4: 63-72. doi: 10.1023/A:1009695031802

Munguira ML, Martín J (Eds) (1999) Action plan for the Maculinea butterflies in Europe. Nature and Environment, No. 97. Council of Europe Publishing, Strasbourg, 64 pp.

Nash DR (2014) MacSamp. http://www.zi.ku.dk/personal/drnash/download/MacSamp.html [Accessed: 08 April 2014]

Nash DR, Als TD, Maile R, Jones GR, Boomsma JJ (2008) A mosaic of chemical coevolution in a large blue butterfly. Science 319: 88-90. doi: 10.1126/science.1149180

Pech P, Fric Z, Konvička M (2007) Species-specificity of the Phengaris (Maculinea)-Myrmica host system: fact or myth? (Lepidoptera: Lycaenidae; Hymenoptera: Formicidae). Sociobiology 50: 983-1003. http://users.prf.jcu.cz/aescu/pech_2007_sociobiology.pdf

Pecsenye K, Bereczki J, Tihanyi B, Tóth A, Peregovits L, Varga Z (2007) Genetic differentiation among the Maculinea species (Lepidoptera: Lycaenidae) in eastern Central Europe. Biological Journal of the Linnean Society 91: 11-21. doi: 10.1111/j.1095-8312.2007.00781.x

Radchenko AG, Elmes GW (2010) Myrmica (Hymenoptera: Formicidae) ants of the Old World. Fauna Mundi 3: 1-789.

Savela M (2014) Lepidoptera and some other life forms. http://ftp.funet.fi/index/Tree_of_life/ insecta/lepidoptera/ditrysia/papilionoidea/lycaenidae/polyommatinae/maculinea/index. html [Accessed 08 April 2014]

Schönrogge K, Wardlaw JC, Thomas JA, Elmes GW (2000) Polymorphic growth rates in myrmecophilous insects. Proceedings of the Royal Society of London, Series B 267: 771-777. doi: $10.1098 / \mathrm{rspb} .2000 .1070$

Seifert B (1988) A taxonomic revision of the Myrmica species of Europe, Asia Minor, and Caucasus (Hymenoptera, Formicidae). Abhandlungen und Berichte des Naturkundemuseums Görlitz 62: 1-75.

Settele J, Kühn E (2009) Insect conservation. Science 325: 41-42. doi: 10.1126/science. 1176892 Settele J, Kühn E, Thomas JA (Eds) (2005) Studies on the ecology and conservation of butterflies in Europe: species ecology along a European gradient: Maculinea butterflies as a model, vol 2. Pensoft Publishers, Sofia-Moscow, 289 pp.

Sielezniew M, Rutkowski R, Ponikwicka-Tyszko D, Ratkiewicz M, Dziekańska I, Švitra G (2012) Differences in genetic variability between two ecotypes of the endangered myrmecophilous butterfly Phengaris (=Maculinea) alcon- the setting of conservation priorities. Insect Conservation and Diversity 5: 223-236. doi: 10.1111/j.1752-4598.2011.00163.x

Sielezniew M, Stankiewicz AM (2004) Simultaneous exploitation of Myrmica vandeli and M. scabrinodis (Hymenoptera: Formicidae) colonies by the endangered myrmecophilous 
butterfly Maculinea alcon (Lepidoptera: Lycaenidae). European Journal of Entomology 101: 693-696. doi: 10.14411/eje.2004.091

Stankiewicz A, Sielezniew M, Švitra G (2005) Myrmica schencki (Hymenoptera: Formicidae) rears Maculinea rebeli (Lepidoptera: Lycaenidae) in Lithuania: new evidence for geographical variation of host-ant specificity of an endangered butterfly. Myrmecologische Nachrichten 7: 51-54. http://myrmecologicalnews.org/cms/images/pdf/volume7/mn7_51-54_non-printable.pdf

Steiner FM, Sielezniew M, Schlick-Steiner BC, Höttinger A, Stankiewicz H, Górnicki A (2003) Host specificity revisited: New data on Myrmica host ants of the lycaenid butterfly Maculinea rebeli. Journal of Insect Conservation 7: 1-6. doi: 10.1023/A:1024763305517 Tartally A (2004) Is Manica rubida (Hymenoptera: Formicidae) a potential host of the Maculinea alcon (Lepidoptera: Lycaenidae) group? Myrmecologische Nachrichten 16: 23-27. http://myrmecologicalnews.org/cms/images/pdf/volume6/mn6_23-27_printable.pdf

Tartally A (2008) Myrmecophily of Maculinea butterflies in the Carpathian Basin (Lepidoptera: Lycaenidae). PhD Thesis, University of Debrecen, Debrecen, Hungary, 97 pp. http://ganymedes.lib.unideb.hu:8080/dea/bitstream/2437/78921/5/ertekezes.pdf [Accessed: 08 April 2014]

Tartally A (2005) Myrmica salina (Hymenoptera: Formicidae) as a host of Maculinea alcon (Lepidoptera: Lycaenidae). Sociobiology 46: 39-43. http://www.researchgate.net/publication/229424075_Myrmica_salina_(Hymenoptera_Formicidae)_as_a_host_of_Maculinea_alcon_(Lepidoptera_Lycaenidae)/file/d912f5009b1e41ac61.pdf

Tartally A, Nash DR, Lengyel S, Varga Z (2008) Patterns of host ant use by sympatric populations of Maculinea alcon and M. "rebeli" in the Carpathian Basin. Insectes Sociaux 55: 370-381. doi: 10.1007/s00040-008-1015-4

Tartally A, Rodrigues MC, Brakels P, Arnaldo PS (2013) Myrmica aloba (Hymenoptera: Formicidae) hosts isolated populations of a hoverfly, a butterfly and an ichneumon species in NEPortugal. Journal of Insect Conservation 17: 851-855. doi: 10.1007/s10841-013-9575-7

Thomas JA, Elmes GW (1998) Higher productivity at the cost of increased host-specificity when Maculinea butterfly larvae exploit ant colonies through trophallaxis rather than by predation. Ecological Entomology 23: 457-464. doi: 10.1046/j.1365-2311.1998.00153.x

Thomas JA, Elmes GW, Schönrogge K, Simcox DJ, Settele J (2005) Primary hosts, secondary hosts and 'non-hosts': common confusions in the interpretation of host specificity in $M a$ culinea butterflies and other social parasites of ants. In: Settele J, Kühn E, Thomas JA (Eds) Studies on the Ecology and Conservation of Butterflies in Europe Vol. 2: Species Ecology along a European Gradient: Maculinea Butterflies as a Model. Pensoft Publisher, SofiaMoscow, 99-104.

Thomas JA, Elmes GW, Wardlaw JC, Woyciechowski M (1989) Host specificity among Maculinea butterflies in Myrmica ant nests. Oecologia 79: 452-457. doi: 10.1007/BF00378660 Thomas JA, Knapp JJ, Akino T, Gerty S, Wakamura S, Simcox DJ, Wardlaw JC, Elmes GW (2002) Parasitoid secretions provoke ant warfare. Nature 417: 505-6. doi: 10.1038/417505a

Thomas JA, Settele J (2004) Evolutionary biology: butterfly mimics of ants. Nature 432: 283-284. doi: 10.1038/432283a 
Tuzov VK (2000) Guide to the Butterflies of Russia and Adjacent Territories: Libytheidae, Danaidae, Nymphalidae, Riodinidae, Lycaenidae. Vol. 2. Pensoft Publisher, Sofia-Moscow. Ugelvig L V, Vila R, Pierce NE, Nash DR (2011) A phylogenetic revision of the Glaucopsyche section (Lepidoptera: Lycaenidae), with special focus on the Phengaris-Maculinea clade. Molecular Phylogenetics and Evolution 61: 237-43. doi: 10.1016/j.ympev.2011.05.016

Witek M, Sliwinska EB, Skorka P, Nowicki P, Wantuch M, Vrabec V, Settele J, Woyciechowski M (2008) Host ant specificity of large blue butterflies Phengaris (Maculinea) (Lepidoptera: Lycaenidae) inhabiting humid grasslands in East-central Europe. European Journal of Entomology 108: 871-877. doi: 10.14411/eje.2008.115

Witek M, Sliwinska EB, Skórka P, Nowicki P, Settele J, Woyciechowski M (2006) Polymorphic growth in larvae of Maculinea butterflies, as an example of biennialism in myrmecophilous insects. Oecologia 148: 729-33. doi: 10.1007/s00442-006-0404-5 